Research Journal of Applied Sciences, Engineering and Technology 6(22): 4186-4191, 2013

DOI:10.19026/rjaset.6.3530

ISSN: 2040-7459; e-ISSN: 2040-7467

(C) 2013 Maxwell Scientific Publication Corp.

Submitted: January 31, $2013 \quad$ Accepted: February 25, $2013 \quad$ Published: December 05, 2013

\title{
Research Article \\ Examining the Relationship between the Dividend Policy and Stock Prices in Companies Listed on Tehran Stock Exchange
}

\author{
Alireza Asadi \\ Department of Accounting, South Tehran Branch, Islamic Azad University, Tehran, Iran
}

\begin{abstract}
This research is applied based on the objective and has the library type in terms of data collection because it is seeking to calculate and explain the relationship between the coefficients of each of the independent variables (dividend policies) with the stock price in Iran by using the econometric models. The document part in library studies and the information related to the research variables were applied in order to collect data necessary for the research and also the annual reports of stock were referred. The objective of this study is to study and examine the relationship between the dividend policy and stock prices in Iran during the years 2007 to 2011. The regression equation was determined based on the obtained results according to the type of relationship among the variables of this study. The normality of data distribution was determined through Kolmogorov-Smirnov test. The Analysis of Variance test was done in order to make sure of the relationship between the independent and dependent variables. Then the regression equation of research variables was calculated. Finally, Friedman test was done in order to rank the dependent and independent variables of model. According to the overall result of this study, there is a direct significant relationship between the variables of earnings per share and cash dividend. Moreover, ranking the variables also indicates the preference of earnings per share to the cash dividends. Finally, the regression model of relationship among the variables of research has been also presented.
\end{abstract}

Keywords: Dividend, earnings per share, stock price

\section{INTRODUCTION}

Dividend policy and its planning strategy are among the tasks of financial departments' management in economic organizations. This task has a significant impact on the capital structure and pricing the company stock. Capital attraction from various sources is the key factor for entering the developing countries into the development process. Capital attraction needs that a part of country resources to be spent in the projects which are attractive to investors. The investment in Iran is higher in purchasing the property and estates and physical assets rather than purchasing the corporate stock. Creating the stock market is one of the symptoms of economic development and its activity will facilitate the corporate financing, direct the micro investment towards the way of production and avoid the small stagnant financial resources and generate the income for the public and will have other relevant advantages related to the stock market. The increase of wealth is one of the main reasons of investment which leads to the capital owners' tendency towards the financial resource allocation.

Obtaining the appropriate returns from the investment is a factor for increase of wealth. In other words, the profitability of securities is one of the main reasons of purchasing them. Cash dividend payment is the most common type of transferring the return on capital by the economic organizations to the shareholders. The policy of cash dividend distribution is not done identically in the economic organization. These policies are different and they range from paying the minimum cash dividends prescribed in the law to the division of revenue from all operations of an economic organization as the payment of earnings per share. Therefore, determining the amount and relation of earnings per share with its price and the trading value of securities and also the attractiveness of this market for the investors is the main concern in the investment markets.

Nowadays, if we want to get an accurate analysis of the markets with complex behavior, we should monitor all effective factors. Dividend policy is one of these factors in the financial markets. Dividend policy in each economic organization plays an important role in the value of its stock. Empirical studies show that there are numerous theories in the field of dividend policy. Each of them focuses on certain aspects of business strategies and pays attention to them. The main issue in this study is to investigate the dividend policy on the stock price of companies listed on the stock exchange.

One of the main objectives of this study is to examine the role and impact of dividends on stock prices, examine the importance and role of paid 
dividends on the stock price and investigate the effect of earnings per share growth rate on the stock price of companies listed on stock exchange.

\section{LITERATURE REVIEW}

In this section, the theoretical principles and research background are provided respectively. As raised from the research subject, the aim of conducting the research is to study the relationship between the dividend policy and the stock price in companies listed on Tehran Stock Exchange. Hence, the Stock Exchange and Dividend Per Share (DPS) are defined in the theoretical principles of research and then the previous conducted studies in this field are briefly described in the research background.

Theoretical principles: Stock market is a kind of market which has the official and organized activity and various activity fields such as stock exchange, commodity exchange and currency exchange and so on. This research studies the stock exchange. Stock exchange is the official and organized market in which the accepted securities are traded between buyers and sellers based on the certain rules. The main task of Stock exchange is to provide the transparent market (providing the full information for buyers and sellers) in order to do daily transactions. Buying and selling the shares on Tehran Stock Exchange is done by and through a computer system. Therefore, in representation of the shareholders, the brokers enter the purchase and sales orders into the transaction system. Transactions in the system are done based on a two-sided auction. In other words, the purchase turns are sorted based on the higher prices at any time and the sales turns sorted based on the minimum price at any time; when the best purchase and sales prices become equal, the transaction is done on the stock. The broker is a legal person by whom the exchange is done on the stock. Brokerage license is given to the individuals who have some of features such as the professional experience, passing the test and being honest as well as to have the conditions of membership in the Brokers Association, be accepted on the stock exchange and have the licenses for activity on the stock exchange according to the Securities Market Act of the Islamic Republic of Iran.

Dividend Per Share (DPS) includes a portion of net profit of public company and is divided among the shareholders. Another undivided portion is held according to the law (legal reserve) based on the needs of companies. Therefore, the dividend per share is obtained from the total dividend by the total number of corporate share. According to the Commercial Code, if the dividend is adopted in the Annual General Assembly, the company should pay the shareholders the DPS within maximum 8 months from the date of approval. Earnings per share is given to the shareholder who owns that share at the date of holding the Annual General Assembly.
A model for determining the effect of dividend policy on the price is presented as follows.

The effect of dividend policy on the price according to Gordon's viewpoint: Gordon dividend model has provided a valuable tool to show the effect of dividend policies on the value of company. He has provided the following hypotheses in his own study on dividend policies.

- There is no external financing. This model includes no variables of debt, interest rate and issuing the new shares and because the retained earnings are the only source for development, the dividend and investment policies should compete for the earnings of company

- Rate of return on investment ( $\mathrm{r}$ ) is constant

- The appropriate discount rate for the company is constant

- The company has an unlimited life

- There is no tax

- Growth rate $(\mathrm{g}=$ fr) remains unchanged

- The following relationship should be always true

$\mathrm{K}=\mathrm{fr}=\mathrm{g}$

If $\mathrm{g}>\mathrm{k}$, the share value will indefinite.

- Dividend policy, showed by f, will always remain constant

By providing these hypotheses, in fact, Gordon differentiated three groups of companies in terms of the way of dividing the share.

- Growing organizations: Companies, which invest their funds with higher returns than the cost of capital, are the growing companies. According to Gordon model, these companies can maximize their own values through retaining all earnings and investment. In fact, if the companies with $r>1$ retain all their earnings, they have done a great mistake. Gordon Model shows that the dividend payment will reduce the value of such these companies

- Organizations with low growth (declining): Companies, which have no profitability investment opportunities, are called the organizations with declining growth. The sale of such these companies is reduced and there is no profitable investment in the company. Indeed, the capital cost in these companies is higher than its return $(\mathrm{K}>\mathrm{r})$. In such cases, the companies can maximize their value by paying the shareholders all they have earned in cash. In fact, the cash payment and paying the cash dividend immediately is the optimal financing decision for them. The shareholders' paid funds can be used in a better investment in the capital system

- Ordinary companied (at maturity): These companies have a few numbers of investment in 
which $r>k$. Such these companies usually are working in a quiet environment. In general, $\mathrm{r}=\mathrm{k}$ for them and the dividend policy has no effect on the activity value based on Gordon model.

Research background: Mancinelli and Ozkan (2006), Ownership structure and Dividend Policy (Naceur et al., 2006). On the Determinants and Dynamics of Dividend Policy (Italy) (Kouki and Guizani, 2009). Ownership Structure and Dividend Policy (Tunisia) (Guo and Ni, 2008). Institutional Ownership and Firm's Dividend Policy (Farinha, 2003). Divided Policy, Corporate Governance and the Managerial Entrenchment Hypothesis (Bichara, 2008). Institutional Ownership and Dividend Policy, A Framework based on tax clientele, information signals and Agency costs (Abdelsalam et al., 2008). Board Composition, Ownership structure and dividend policies in an emerging Market (Ali Saghafi and Motamedi, 2011). Examining the relationship between the audit quality and investment efficiency in the companies with high investment facilities (Khajavi et al., 2011). Examining the efficiency model and model of price in the companies listed on Tehran Stock Exchange through using the panel model with balanced data (Sinaiee et al., 2012). The effect of growth opportunities on the relationship between the capital structure, dividends and ownership structure with the firm value (Karami and Eskandar, 2009). Shareholders Composition and dividend policy (Soltani and Momeni, 2011). An overview of the factors affecting the stock dividend policy and the possibility of dividends payment (Setayesh and Kazemnejad, 2009). Investigating the effect of ownership structure and board composition on the dividend policy of companies listed on Tehran stock exchange (Jahankhani and Ghorbani, 2005). Explaining the determinants of dividend policy in companies listed on Tehran stock exchange (Hashemi and Ethical, 2010). An overview of literature of financial leverage and dividend policies and their impact on the firm value (Sadeghi Sharif and Bahadori, 2009). The impact of ownership structure on the ratio of dividend payment in companies listed on Tehran Stock Exchange (Etemadi and Banani, 2007). Examining the relationship between the stock cash dividends with the economic added value and return on assets in companies listed on Tehran Stock Exchange (Bozorg and Sarafraz, 2009). The relationship between the stable dividend policy with the firm stock returns, Journal of Economics, Accounting Studies (Babalouyan and Bakhshiayani, 2008). The ratio of dividends, theoretical price and actual price after the assembly (Safarpour and Safarpour, 2008). Examining the relationship between the operating profit changes and changes of stock returns in automobile and parts manufacturing companies listed on Stock Exchange; (Barzideh and Borhani, 2008). Usefulness of dividends information about the future profits (Etemadi and Chalaki, 2005). The relationship between the performance and cash dividends in companies listed on Tehran Stock Exchange during the years 1998 to 2002 (Jahankhani and Ghorbani, 2005). Identifying and explaining the determinants of dividend policy in companies listed on Tehran Stock Exchange.

\section{RESEARCH METHODOLOGY}

This research is applied based on the objective and has the library type in terms of data collection because it is seeking to calculate and explain the relationship between the coefficients of each of the independent variables (dividend policies) with the stock price in companies listed on Tehran Stock Exchange by using the econometric models. The document part in library studies and the information related to the research variables were applied in order to collect data necessary for the research and also the annual reports of stock were referred. The spatial domain of capital market research in Iran includes the companies listed on Tehran Stock Exchange and the time domain of research is 5 years. 165 selected companies were chosen randomly by the calculation and through the method, which is mentioned below, from four available markets including the main and subsidiary boardsshares and the priority of listed companies on the main board, shares and priority of companies listed on subsidiary board, shares and priority of companies listed on informal board, corporate and government Bonds Market.

Statistical population: Statistical population of this research includes the companies listed on Tehran Stock Exchange during the tears 2007-2011. Thus, the sample size will be calculated by using the following equation:

$$
n=\frac{z_{\frac{\alpha}{2}}^{2}}{(d)^{2}} \times \sigma^{2}
$$

$z_{\frac{\alpha}{2}}^{2}=$ The area under the normal curve with the significant level $(1-\propto) \%$

$d=$ Amount of error

$\sigma^{2}=$ Sample variance

Given the number of companies listed on Tehran Stock Exchange and 4 available markets in the Stock Exchange, the statistical population is estimated equal to 165 companies by using the above equation.

Research hypotheses: For developing the main hypothesis, this question is raised whether there is a significant relationship between the dividend policy as the independent variable and the stock price as the dependent variable? In answering this question, the research assumptions are determined as follows. Dividend policies in this study are classified into two main categories. 


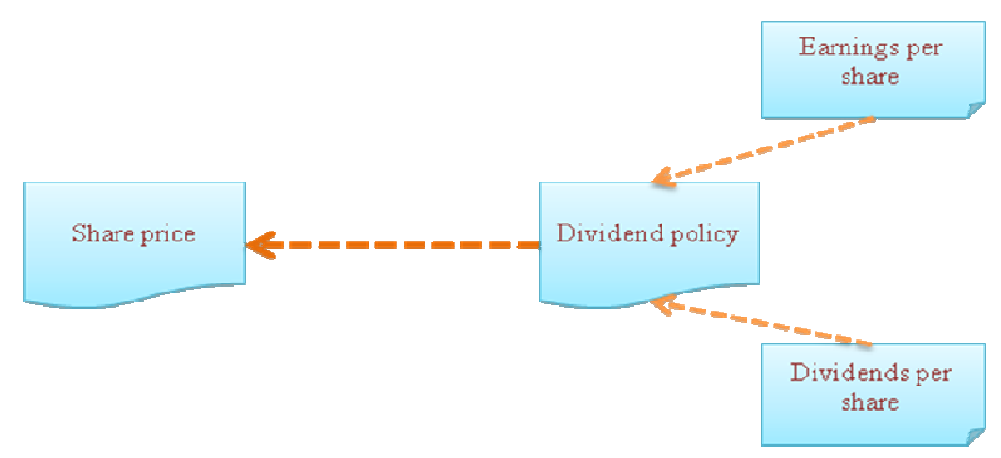

Fig. 1: Conceptual model of research

- Main hypothesis: There is a significant relationship between the Earnings per share and dividends per share with the stock price

\section{- Subsidiary hypotheses:}

$\mathbf{H}_{01}$ : There is a significant relationship between the earnings per share and stock price

$\mathbf{H}_{11}$ : There is no significant relationship between the earnings per share and stock price

$\mathbf{H}_{\mathbf{0 2}}$ : There is a significant relationship between the dividends per share and the stock price

$\mathbf{H}_{12}$ : There is no significant relationship between the dividends per share and the stock price

Conceptual model of research: Conceptual model of the relationship between the independent variables of research (dividend policies) and the dependent variable (stock price) is presented in Fig. 1. As it can be seen, the dividend policies have been classified into two policies, earnings per share and cash dividend, respectively.

\section{RESULTS}

In this chapter, the research findings are reviewed and analyzed according to the presented contents. Each of the hypotheses is studied according to the described statistical methods. Given the kind of relationship between the main and subsidiary variables, this study is seeking to determine the regression equation of obtained results after determining the type of relationship between the research hypotheses. Therefore, first it determines the normality of data distribution and then used Pearson correlation test in order to determine the significant relationship or lack of it between the dependent and independent variables. Calculations are performed through the software SPSS.

Kolmogorov-Smirnov test: This test is used in order to determine the distribution normality of dependent variable. The results are shown in Table 1.
Table 1: Results of Kolmogorov-Smirnov test

\begin{tabular}{lll}
\hline & $\begin{array}{l}\text { Earnings per } \\
\text { share }\end{array}$ & $\begin{array}{l}\text { Dividends } \\
\text { per share }\end{array}$ \\
\hline Kolmogorov-Smirnov Z & 0.970 & 0.702 \\
Asymp. Sig. (2-tailed) & 0.304 & 0.708 \\
\hline
\end{tabular}

As seen in the above output, the results of sig are higher than 0.05 . Thus the assumption of normal data is confirmed. Pearson correlation test is presented as follows in order to determine the relationship among the research variables.

Analysis of Variance test (ANOVA): ANOVA test has been done through software SPSS and its results are presented in Table 2.

Given that the obtained sig is less than five percent, the hypothesis of a linear relationship is accepted. Now, the coefficients of independent variables are determined in order to find the regression equation of above hypotheses. The results are shown in Table 3:

Regression equation of first hypothesis: $\mathrm{Y}=$ 4.628x-2426.479

Regression equation of second hypothesis: $\mathrm{Y}=$ 5.519x-2309.980

Equation of regression line: $\mathrm{Y}=3.631 \mathrm{X}_{1}+3.530 \mathrm{X}_{2}$ 1244.503

According to the determined regression equations, Friedman rank test is done as follows in order to determine the rank of dependent and independent variables of model.

Friedman rank test: This test is done by the software SPSS and the results are presented in Table 4.

Calculations indicate that the stock price in the model of this study has the first rank; the Earning per share has the second rank; and the dividend per share has the third rank. Given the process of calculations, it is concluded that the stock price has the direct relationship with the earnings per share and dividends per share. In other words, any effect on the dividend has a direct impact on the firm stock price. As a result, the people, who are willing to invest in the stock market, 
Res. J. Appl. Sci. Eng. Technol., 6(22): 4186-4191, 2013

Table 2: Results of ANOVA test

\begin{tabular}{|c|c|c|c|c|c|c|}
\hline \multirow{4}{*}{$\begin{array}{l}\text { Model } \\
\text { EPS }\end{array}$} & & SS & $\mathrm{df}$ & Mean square & $\mathrm{F}$ & Sig. \\
\hline & Regression & 2.448 & 1 & 2.448 & 11.100 & 0.001 \\
\hline & Residual & 3.595 & 163 & 22056166.27 & & \\
\hline & Total & 3.840 & 164 & & & \\
\hline \multirow[t]{3}{*}{ DPS } & Regression & 1.968 & 1 & 1.968 & 8.807 & 0.003 \\
\hline & Residual & 3.643 & 163 & 22350576.16 & & \\
\hline & Total & 3.840 & 164 & & & \\
\hline \multirow[t]{3}{*}{ EPS and DPS } & Regression & 3.163 & 2 & 1.581 & 7.270 & 0.001 \\
\hline & Residual & 3.524 & 162 & 21751363.78 & & \\
\hline & Total & 3.840 & 164 & & & \\
\hline
\end{tabular}

Table 3: Results of computational coefficients of the independent variables

\begin{tabular}{|c|c|c|c|c|c|}
\hline \multirow[b]{2}{*}{ Model } & \multicolumn{5}{|c|}{ Unstandardized coefficients } \\
\hline & B & S.E. & $\beta$ & $\mathrm{t}$ & Sig. \\
\hline \multirow[t]{2}{*}{ (Constant)EPS } & 2426.479 & 869.160 & 0.253 & 2.792 & 0.006 \\
\hline & 4.628 & 1.389 & & 3.332 & 0.001 \\
\hline \multirow[t]{2}{*}{ (Constant)DPS } & 2309.980 & 995.076 & 0.226 & 2.321 & 0.022 \\
\hline & 5.519 & 1.860 & & 2.968 & 0.003 \\
\hline \multirow[t]{3}{*}{ (Constant)EPS DPS } & 1244.503 & 1081.850 & 0.149 & 1.150 & 0.252 \\
\hline & 3.631 & 2.004 & 0.193 & 1.812 & 0.072 \\
\hline & 3.530 & 1.507 & & 2.343 & 0.020 \\
\hline
\end{tabular}

Table 4: Friedman rank test

\begin{tabular}{llllll}
\hline Variable & Mean rank & $\mathrm{N}$ & $\begin{array}{l}\text { Chi- } \\
\text { square }\end{array}$ & df & $\begin{array}{l}\text { Asymp. } \\
\text { Sig. }\end{array}$ \\
\hline Price & 3.00 & 165 & 256.158 & 2 & 0.000 \\
EPS & 1.65 & & & & \\
DPS & 1.35 & & & & \\
\hline
\end{tabular}

can invest in various fields according to their own investment field and also the level of risk-taking. Furthermore, the companies can make the necessary decisions for future measures according to their investors' predicted behavior.

\section{CONCLUSION}

The objective of this study is to study the relationship between the dividend policy and the stock prices in Iran during the years 2007 to 2011 . According to the type of relationship between the variables of this study, the regression equation is determined based on the obtained results. Therefore, the normality of data distribution is initially determined through Kolmogorov-Smirnov test (Table 1) and then the ANOVA test was done for certainty of the relationship between the independent and dependent variables. Thereupon the coefficients of independent variables are estimated in order to determine the regression equation of above hypotheses. Finally, Friedman test was done in order to rank the dependent and independent variables of model.

Experimental and theoretical studies indicate the relationship between the dividend policies and the stock price in various markets of stock exchange. This relationship has been estimated as a direct or reverse correlation according to the economic conditions, the rules governing the stock markets and equity, diversity of its tools, etc, in some countries. Despite the fact that the activity of financial sector in Iran during the studied period has been developed in terms of size and activity and its importance has been enhanced in the economy compared to the previous periods, the fluctuations of inflation and economic growth indicate the lack of integration of fiscal policies affecting the stock markets or the irrelevance of these policies to the long-term plans for supporting thee stock markets in Iran. Thus it is suggested that:

- Using the similar studies, the dividend policies should go in a way under which the investors show positive process of support and welcoming the stock markets with the financial feeling and guaranteed profits

- In line with determining the relationship between the dividend policies and stock prices, the scientists and other researchers should determine the structural equations and determine and calculate new regression functions based on defining its variables by using the long term periods

- The computational model of this study should be compared with other stock markets, the differences, resulted from the findings, should be analyzed, the impact of economic factors, affecting the stock markets, should be investigated and compared with Iran.

\section{REFERENCES}

Abdelsalam, O., A. EL-Masry and S. Elsegini, 2008. Board composition, ownership structure and dividend policies in an emerging market. J. Manage. Financ., 34(12): 953-964.

Ali Saghafi, M. and F. Motamedi, 2011. Examining the relationship between the audit quality and investment efficiency in the companies with high investment facilities. Q. J. Financ. Account. Res., Third Year, No. 4(Serial 10): 1.

Babalouyan, S. and A. Bakhshiayani, 2008. The ratio of dividends, theoretical price and actual price after the assembly. J. Econ. Stock Market, 72: 34-39. 
Barzideh, F. and S.M. Borhani, 2008. Usefulness of dividends information about the future profits. J. Econ. Account. Stud., 23: 67-88.

Bichara, L., 2008. Institutional ownership and dividend policy: A framework based on tax clientele, information signals and agency costs. Ph.D. Thesis, University of North Texas.

Bozorg, A.M. and A.A. Sarafraz, 2009. The relationship between the stable dividend policy with the firm stock returns. J. Econ. Account. Stud., pp: 105-126.

Etemadi, H. and M. Banani, 2007. Examining the relationship between the stock cash dividends with the economic added value and return on assets in companies listed on Tehran stock exchange. J. Econ. Account. Stud., 19: 73-92.

Etemadi, H. and P. Chalaki, 2005. The relationship between the performance and cash dividends in companies listed on Tehran stock exchange during the years 1998 to 2002. J. Econ. Rev. Account. Audit. Sci. Res., 39: 31-48.

Farinha, J., 2003. Divided policy, corporate governance and the managerial entrenchment hypothesis: An empirical analysis. J. Bus. Finan. Account., 30: 1173-1209.

Guo, W. and J. Ni, 2008. Institutional ownership and firm's dividend policy. Corp. Ownership Control, 5(2): 128-136.

Hashemi, A. and H.A. Ethical, 2010. An overview of the literature on financial leverage and dividend policies and their impact on firm value. J. Econ. Account. Financ. Manage., 3: 152-166.

Jahankhani, A. and S. Ghorbani, 2005. Identifying and explaining the determinants of dividend policy in companies listed on Tehran stock exchange. J. Econ. Financ. Res., 20: 27-48.

Karami, G. and H. Eskandar, 2009. Shareholders composition and dividend policy. J. Econ. Account., 209: 53-57.
Khajavi, S., H. Yari Abhari and M. Ghasemi, 2011. Examining the efficiency model and model of price in the companies listed on Tehran stock exchange through using the panel model with balanced data, pp: 55 .

Kouki, M. and M. Guizani, 2009. Ownership structure and dividend policy: Evidence from the Tunisian stock market. Eur. J. Sci. Res., 25(1): 42-53.

Mancinelli, L. and A. Ozkan, 2006. Ownership structure and dividend policy: Evidence from Italian firms. Eur. J. Financ., 12(3): 265-282.

Naceur, S., M. Goaied and A. Belanes, 2006. On the determinants and dynamics of dividend policy. Int. Rev. Financ., 6(1): 1-23.

Sadeghi Sharif, J. and H. Bahadori, 2009. The impact of ownership structure on the ratio of dividend payment in companies listed on Tehran stock exchange. J. Econ. Financ. Res., 28: 61-80.

Safarpour, M. and J. Safarpour, 2008. Examining the relationship between the operating profit changes and changes of stock returns in automobile and parts manufacturing companies listed on Stock Exchange. J. Econ. Account., 199: 11-19.

Setayesh, M.H. and M. Kazemnejad, 2009. Investigating the effect of ownership structure and board composition on the dividend policy of companies listed on Tehran stock exchange. J. Econ. Account. Knowl., 1: 29- 52.

Sinaiee, H., M. Solgi and K. Mohammadi, 2012.The effect of growth opportunities on the relationship between the capital structure, dividends and ownership structure with the firm value. 3(4): 87102. Retrieved form: http://uijs.ui.ac.ir/far/ browse. php?a_code $=$ A-10-12-5\&slc_lang $=$ en \& sid $=1$.

Soltani, A. and Z. Momeni, 2011. An overview of the factors affecting the stock dividend policy and the possibility of dividends payment. J. Econ. Account. Financ. Manage., 7: 56-68. 